\title{
Estimation of Genetic Parameters of Turiaçu Pineapple Clones and Genetic Correlation between Traits
}

\author{
Guilherme Barbosa Abreu ${ }^{1 *}$, Marcos Miranda Toledo1, Marcelo Mattos Cavallari², \\ José Ribamar Gusmão Araújo ${ }^{3}$, Antônia Alice Costa Rodrigues ${ }^{3}$, \\ Luiz Gustavo de Lima Melo ${ }^{4}$, Augusto César Vieira Neves Júnior ${ }^{3}$ \\ ${ }^{1}$ Embrapa Cocais (CPACP), São Luis, Brazil \\ ${ }^{2}$ Embrapa Pecuária Sudeste (CPPSE), São Carlos, Brazil \\ ${ }^{3}$ Universidade Estadual do Maranhão (UEMA), São Luis, Brazil \\ ${ }^{4}$ Universidade Federal Rural de Pernambuco (UFRPE), Recife, Brazil \\ Email: *Guilherme.abreu@embrapa.br
}

How to cite this paper: Abreu, G.B., Toledo, M.M., Cavallari, M.M., Araújo, J.R.G., Rodrigues, A.A.C., de Lima Melo, L.G. and Júnior, A.C.V.N. (2017) Estimation of Genetic Parameters of Turiaçu Pineapple Clones and Genetic Correlation between Traits. Agricultural Sciences, 8, 1253-1262.

https://doi.org/10.4236/as.2017.811090

Received: September 29, 2017

Accepted: November 10, 2017

Published: November 13, 2017

Copyright $\odot 2017$ by authors and Scientific Research Publishing Inc. This work is licensed under the Creative Commons Attribution-NonCommercial International License (CC BY-NC 4.0). http://creativecommons.org/licenses/by-nc/4.0/ (c) (i) \& Open Access

\begin{abstract}
This study aimed to estimate genetic parameters of Turiaçu pineapple clones using mixed models; and estimate genetic correlation coefficient between traits, to provide important information to breeding programs. For this, 19 pineapple plants were visually selected and its slips were collected and planted in a single environment and nine traits were evaluated. The genetic parameters of most evaluated traits presented significant differences between the 19 clones. Some traits, such as Fusarium wilt resistance, showed high magnitudes of heritability. Clones did not differ in relation to total titratable acidity (TTA) and total soluble solids (TSS). However, these traits, which have implications to fruit quality, showed to be negatively correlated to fruit mass $(-0.46$ and $-0.67)$. The results indicate that the population of Turiaçu pineapple is suitable for selection, especially for Fusarium wilt resistance. Also, Turiaçu clones can be used in breeding programs of pineapple.
\end{abstract}

\section{Keywords}

Quantitative Genetics, Plant Breeding, Ananas comosus

\section{Introduction}

The pineapple (Ananas comosus) is an important fruit crop in the state of Maranhão, Brazil. An area of about 1388 ha was used to grow this fruit in 2014 [1]. The main part of this area is cultivated by family farmers, and the activity is the 
primary source of income for many families.

One of the municipalities that stands out on this fruit production is Turiaçu, located in Gurupi region [1]. In Turiaçu, there is a variety of pineapple of unknown origin and genetic identity that has been cultivated for decades by family farmers in the region. This variety of pineapple has unique features such as high content of soluble solids when compared to Pérola cultivar [2]. The quality of fruit enables the variety to gain prominence in marketplaces throughout Maranhão, and the variety is considered popularly the sweetest pineapple of Brazil. The price of Turiaçu pineapple gets up to double the price of other varieties in the market [2].

Turiaçu pineapple is not a registered cultivar. There are no records of genetic breeding for productivity and quality for it, and the crop is normally cultivated with low technology, resulting in low productivity. The current consolidation of the Turiaçu variety in the market indicates that introduction of new varieties may not be a good strategic choice. Therefore, genetic breeding for productivity and quality of fruit may be a good opportunity and would bring economic benefits to farmers.

The Fusarium wilt, a disease caused by the fungus Fusarium guttiforme (synonymy Fusarium subglutinans f. sp. ananas) affects the production of pineapple in most part of Brazil. According to [2], the Turiaçu pineapple is resistant to this fungus in native growing conditions. However, there are no records of experiments that aimed to verify this information. The lack of infection in Turiaçu can be caused by a genetic resistance or simply by the absence of the pathogen in the region, since no other variety of pineapple susceptible to the Fusarium is grown in Turiaçu.

One way to increase productivity and/or quality of any crop is through genetic breeding. Recently, there has been a large increase in productivity of major crops around the world, and $50 \%$ of this increase was due to conventional genetic breeding [3]. To achieve success in genetic breeding, it is necessary to analyze whether there is genetic variation in the trait within the population. Therefore, it is essential to estimate genetic and phenotypic parameters [4].

The prediction of genetic values and selection methods depends, basically, on the variance component estimates. Usually, the variance components are estimated by least squares methods, such as analysis of variance procedures. These procedures allow working with a certain level of unbalance and it is equal of usual variance analysis when data are balanced. On the other hand, there is another situation of genetic values prediction where variances are unknown and the imbalances are such that the method of least squares presents unknown efficiency. In these situations, other estimation procedures of components of variance are demanded, and the prediction of genetic values must be performed simultaneously to the estimation of variance components, i.e., the variance component estimation by restricted maximum likelihood (REML) and the prediction of genetic values by best linear unbiased prediction (BLUP) [5]. Mixed 
models by REML/BLUP have been widely used in plant breeding to estimate genetic parameters [6], adaptability and stability of crops [7], genotype $x$ environment interaction [8], among others.

In addition to genetic parameters, the correlation between traits is also important to plant breeding. Breeding programs must attempt to improve traits of interest without selecting correlated bad traits [9]. Moreover, known correlation estimates allow performing indirect selection of traits that are difficult to evaluate that makes the selection procedure easier [10].

This study aimed to estimate genetic parameters of Turiaçu pineapple clones through mixed models and to estimate the genetic correlation among traits.

\section{Material and Methods}

To set up the experiment, 19 plants with the better fruit from farms in the rural village of Serra dos Paz, Turiaçu, Maranhão, Brazil (01 $\left.39^{\prime} 48^{\prime \prime} S ; 45^{\circ} 22^{\prime} 18^{\prime \prime} \mathrm{W}\right)$, were visually selected (mass selection) and slips of these plants were collected in 2013. The slips were planted in randomized design scheme in the same municipality, with six replications, in a single environment. The experimental plot was composed of one plant. Eighteen months after planting, the fruits were harvested, the number of slips for each plant was counted and the plant height was measured. The fruits were transported to the Plant and Postharvest Laboratory of Universidade Estadual do Maranhão, where total fruit mass, fruit mass without crown, crown mass and pulp mass were measured individually. Additional procedures were performed as follows.

To chemical analysis, the juice of each peeled fruit was extracted using a blender. Juice samples were used to determine total titratable acidity (TTA) and total soluble solids (TSS) using the following methods:

TTA: $10 \mathrm{~g}$ of juice sample were diluted in $60 \mathrm{~mL}$ of distilled water. This solution was titrated with sodium hydroxide $(\mathrm{NaOH}) 0.1 \mathrm{~N}$ in a burette until $\mathrm{pH}$ reaches 8.1. The $\mathrm{pH}$ of the solution was monitored with a $\mathrm{pH}$ meter Model MPA-210. The results were obtained by the following Equation (1) [11]:

$$
\operatorname{TTA}(\%)=(N \times V \times E q \cdot w t) /(W \times 10)
$$

where: $N$ is the normality of titrant; $V$ is the volume of titrant used; $E q . w t$ is equivalent weight of predominant acid and $W$ is the volume of the sample.

TSS: one or more drops of juice sample were placed in an analogic refractometer until the surface of the prism was fully covered, and them the measurement was done. This process was done at least two times, until two measurements in sequence presented a difference of less than $0.4^{\circ}$ BRIX.

The resistance to Fusarium wilt was verified in the 19 clones. The $F$. guttiforme isolate was obtained from an infected plant on a pineapple farm of another region, located in São Domingos do Maranhão. This isolate was inoculated on D-type leaves collected from the 12 months old clones.

D-type leaves were washed with soap and water, sterilized with a $5 \%$ sodium 
hypochlorite solution and rinsed with distilled water. After that, the inoculation was done at $2 \mathrm{~cm}$ from the base of the leaves by drilling the tissue with a toothpick covered with pathogen.

The leaves were placed on plastic trays wrapped by transparent polyethylene bags. Moistened cotton was placed inside the bags to maintain a humid environment. The trays were kept for 20 days at $25^{\circ} \mathrm{C} \pm 2^{\circ} \mathrm{C}$ and under a photoperiod of 12 hours. The clone resistance was evaluated by measuring the length of the lesion area with a ruler. The clone showed resistance when there was no lesion (length equal to zero).

The software Selegen [5] was used to perform the Genetic-statistical analysis, by Mixed models (REML/BLUP), where the variation components are associated with univariate analysis. The model used was (2):

$$
y=X u+Z g+e
$$

where: $y$ is the data vector; $u$ is the scalar of the general mean (fixed effect); $g$ is the vector of genotypic effects (assumed random); and $e$ is the vector of errors (random). The capital letters represent the incidence matrices for these effects.

The mixed model equations used to estimate the general mean and the prediction of genetic values is equivalent to (3):

$$
\left[\begin{array}{lc}
X^{\prime} X & X^{\prime} Z \\
Z^{\prime} X & Z^{\prime} Z+I\left(\sigma_{e}^{2} / \sigma_{g}^{2}\right)
\end{array}\right]\left[\begin{array}{l}
\hat{u} \\
\hat{g}
\end{array}\right]=\left[\begin{array}{c}
X^{\prime} y \\
Z^{\prime} y
\end{array}\right]
$$

where $I$ is an identity matrix; $\sigma_{g}^{2}$ is genotypic variance and $\sigma_{e}^{2}$ is residual variance.

According to the model, the REML estimators by EM algorithm to obtain estimates of the variance components $\sigma_{g}^{2}$ (4) and $\sigma_{e}^{2}$ (5) were:

$$
\begin{gathered}
\hat{\sigma}_{e}^{2}=\left[y^{\prime} y-\hat{b}^{\prime} X^{\prime} y-\hat{g} Z^{\prime} y\right] /[N-r(X)] \\
\hat{\sigma}_{g}^{2}=\left[g^{\prime} g+\hat{\sigma}_{e}^{2} t r C^{22}\right] / N_{g}
\end{gathered}
$$

where $N_{g}$ is the number of random elements (individuals); $I$ identity matrix; $t r$ is the matrix trace operator, given by the sum of the diagonal elements of the matrix; $N$ is the total number of data; $r(X)$ is the rank of number of linearly independent columns of $X$; and $C^{22}$ is as follows (6):

$$
\left[\begin{array}{ll}
C^{11} & C^{12} \\
C^{21} & C^{22}
\end{array}\right]=\left[\begin{array}{lc}
X^{\prime} X & X^{\prime} Z \\
Z^{\prime} X Z^{\prime} Z+I\left(\sigma_{e}^{2} / \sigma_{g}^{2}\right)
\end{array}\right]^{-1}
$$

The heritability $\hat{h}^{2}(7)$ and the variation components $C V_{g}$ (8) and $C V_{e}$ (9) were obtained as shown below:

$$
\begin{gathered}
\hat{h}^{2}=\hat{\sigma}_{g}^{2} /\left(\hat{\sigma}_{g}^{2}+\hat{\sigma}_{e}^{2}\right) \\
C V_{g}=\hat{\sigma}_{g} / \bar{Y} \\
C V_{e}=\hat{\sigma}_{e} / \bar{Y}
\end{gathered}
$$

where $\hat{\sigma}_{g}^{2}$ is the estimated genetic variance; $\hat{\sigma}_{e}^{2}$ is the estimated 
environmental variance; $C V_{g}$ is the genetic coefficient of variation; $C V_{e}$ is the environmental coefficient of variation; $\hat{h}^{2}$ is heritability in plot level; $\bar{Y}$ is the mean of the evaluated traits.

To verify the significance of genotypes, the analysis of deviance was used. For this, deviances were obtained running the model with and without heritability values for each trait, and then subtracting them and comparing them to the Chi-square value at 1 and 5\% level, with 1 degree of freedom [5]. The genetic correlation between traits (10) was estimated by the Model 102 of Selegen software [5], which adopts the following estimator:

$$
\hat{r}_{g}=\operatorname{COV}\left(\hat{X}_{g}, \hat{Y}_{g}\right) / \sqrt{\hat{\theta}_{\hat{X}_{g}}^{2} \hat{\theta}_{\hat{Y}_{g}}^{2}}
$$

where:

$\hat{r}_{g}=$ estimation of genetic correlation between variables $X$ and $Y$;

$\mathrm{COV}=$ covariance operator;

$\hat{X}_{g}=$ Estimator of genotypic value of variable $X$;

$\hat{Y}_{g}=$ Estimator of genotypic value of variable $Y$;

$\hat{\theta}_{\hat{X}_{g}}^{2}=$ Genetic variation estimation of the estimated genotypic value of variable $X$

$\hat{\theta}_{\hat{V}}^{2}=$ Genetic variation estimation of the estimated genotypic value of variable $Y$.

\section{Results and Discussions}

Table 1 shows the deviance analysis of the nine evaluated traits. Number of slips, pulp mass, plant height and crown mass displayed significant differences at the $5 \%$ level. Only the TTA and TSS did not showed significant differences at the Chi-square test. These traits are important because the titratable acidity is related to

Table 1. Analysis of deviance for pulp mass (PM), plant height (H), number of slips (NS), fruit mass (FM), fruit mass without crown (FLWC), mass of crown (MC), resistance to Fusarium (RF), total soluble solids (TSS) and total titratable acidity (TTA).

\begin{tabular}{ccc}
\hline Traits & Deviance & $\operatorname{LRT}\left(x^{2}\right)^{1 /}$ \\
\hline PM & -57.25 & $6.27^{*}$ \\
H & -119.93 & $3.88^{*}$ \\
NS & 63.91 & $6.59^{*}$ \\
FM & -32.82 & $7.00^{* *}$ \\
FMWC & -35.63 & $6.89^{* *}$ \\
MC & -192.09 & $5.35^{*}$ \\
RF & 93.13 & $62.38^{* *}$ \\
TSS & 44.69 & $1.62^{\mathrm{NS}}$ \\
TTA & -91.27 & $2.25^{\mathrm{NS}}$ \\
\hline
\end{tabular}

${ }^{1 /} \operatorname{LTR}\left(x^{2}\right)$ Chi square of the likelihood ratio test for progeny effect, $\mathrm{x}^{2}$ tabled: 3.84 and 6.63 for the $5\left({ }^{*}\right)$ and $1 \%\left({ }^{* *}\right)$ levels of significance respectively. NS: non-significant. 
tartness and TTS ( ${ }^{\circ}$ Brix) is related to perceived sweetness [12]. Despite the fact that these traits did not showed to be different among the clones evaluated, according to [2] there are differences between the Turiaçu pineapple and other commercial cultivars. This implies that Turiaçu can be used in breeding programs to improve these traits in other cultivars. There is a worldwide tendency of market growth for low acidity fruits, and the development of pineapple cultivars for fresh fruit consumption has been a recent major focus of breeding and selection programs [13]. Considering the renowned sweetness of Turiaçu pineapple, it would be an interesting choice for breeding programs.

The estimates of genetic variance, environmental variance, phenotypic variance, heritability, genetic and environmental variation coefficient, and ratio $C V_{g} / C V_{e}$ of evaluated traits in Turiaçu pineapple clones were presented in Table 2.

Fusarium resistance showed the higher magnitude of heritability. This result indicates that, for the studied population, genetic breeding may be more effective if focused on this trait of high heritability. In a breeding program for resistance to disease, one of the most important issues is the choice of the parents to obtain populations where the selection will be carried out or they will be used for the obtaining of hybrids [14]. In Turiaçu's pineapple population is possible to choose good parents as source of resistance to fusarium. Resistance to Fusarium wilt is an important trait, as this is a highly destructive disease [15]. The use of resistant cultivars reduces the use of fungicides and, consequently, reduces the cost of production and also environmental pollution, besides to enhance the food security. This result for Fusarium resistance was expected because the inheritance of this trait may be linked to a gene (or a few genes) with dominant

Table 2. Genetic parameters for plant height (H), number of slips (NS), fruit mass (FM), mass of crown (MC), fruit mass without crown (FLWC), pulp mass (PM), resistance to Fusarium (RF), total soluble solids (TSS) and total titratable acidity (TTA).

\begin{tabular}{cccccccc}
\hline Traits & $\hat{\sigma}_{g}^{2}$ & $\hat{\sigma}_{e}^{2}$ & $\hat{\sigma}_{f}^{2}$ & $\hat{h}^{2}$ & $C V_{g}(\%)$ & $C V_{e}(\%)$ & $C V_{g} / C V_{e}$ \\
\hline H (meters) & 0.0038 & 0.0061 & 0.0099 & 0.3853 & 73.483 & 92.817 & 0.7917 \\
NS & 74.895 & 12.104 & 86.999 & 0.8609 & 438.155 & 176.142 & 24.875 \\
FM (kg) & 0.0786 & 0.0520 & 0.1306 & 0.6020 & 275.219 & 223.780 & 12.299 \\
MC (kg) & 0.0004 & 0.0003 & 0.0007 & 0.5767 & 227.577 & 194.968 & 11.672 \\
FMWC (Kg) & 0.0861 & 0.0488 & 0.1350 & 0.6379 & 327.812 & 246.943 & 132.747 \\
PM (kg) & 0.0349 & 0.0224 & 0.0573 & 0.6096 & 297.258 & 237.843 & 12.498 \\
RF (mm) & 384.886 & 0.3156 & 388.043 & 0.9918 & 824.439 & 74.663 & 110.421 \\
TSS (Brix) & 14.500 & 0.6061 & 20.562 & 0.7052 & 69.148 & 44.707 & 15.467 \\
TTA (\%) & 0.0103 & 0.0036 & 0.0139 & 0.7419 & 173.526 & 10.234 & 16.956 \\
\hline
\end{tabular}

$\hat{\sigma}_{g}^{2}$ : estimates of genetic variance; $\hat{\sigma}_{e}^{2}$ : estimates of environmental variance; $\hat{\sigma}_{f}^{2}$ : estimates of phenotypic variance; $\hat{h}^{2}$ : heritability; $C V_{g}(\%)$ : genetic variation coefficient; $C V_{e}(\%)$ : environmental variation coefficient; $C V_{g} / C V_{e}:$ ratio $C V_{g} / C V_{e}$ 
character in relation to susceptibility. Therefore, it is a qualitative inheritance that is related to vertical or specific resistance to disease [16]. As the propagation of pineapple is done asexually, both the additive and dominance effects are passed to offspring, so the broad sense heritability has great importance in the genetic breeding of this species.

The $C V_{g} / C V_{e}$ ratio is of great importance to genetic breeding because it indicates the possibility of genetic gains by selection. According to [17], when the ratio is greater than 1.0, the situation is favorable to selection. In this study, the estimate ranged from 0.7917 to 11.0421 (as to plant height and resistance to fusarium, respectively). All but one trait showed $C V_{g} / C V_{e}$ values higher than 1.0, implying that considerable gains are possible through genetic breeding.

Even the number of slips displayed a high $C V_{g} / C V_{e}$ value. This is an important trait for farmers because they use these slips for future plantings, the slips protect the fruits from sunburn [18] and they can be sold, which ensures an extra source of income [19].

Pulp mass can be considered an important trait for pineapple processing industry. In this case, the producers may receive income per pulp mass, and not per fruit, as it is commonly marketed in the region now. This trait also showed $C V_{g} / C V_{e}$ greater than 1 , indicating that the selection of fruits with higher pulp mass can be a viable strategy.

Table 3 shows results of correlation analysis. Fruit mass, fruit mass without crown and pulp mass are highly correlated (correlation close to 1.0). This indicates that it is not necessary to perform evaluations for these three traits, making the evaluation process easier.

Also, it is possible to observe that TSS and TTA are negatively correlated to fruit mass, i.e., smaller fruits will have more TSS and TTA, and this will have

Table 3. Genetic correlation among pulp mass (PM), plant height $(\mathrm{H})$, number of slips (NS), fruit mass (FM), fruit mass without crown (FLWC), mass of crown (MC), resistance to usarium (RF), total soluble solids (TSS) and total titratable acidity (TTA). Values above the diagonal are the genetic correlation and values below diagonal are the significance level ( $\mathrm{p}$ value).

\begin{tabular}{cccccccccc}
\hline Traits & PM & H & NS & FM & FMWC & MC & RF & TSS & TTA \\
\hline PM & 1 & 0.65 & 0.79 & 0.99 & 0.99 & 0.60 & -0.39 & -0.46 & -0.67 \\
H & 0.015 & 1 & 0.71 & 0.62 & 0.65 & 0.06 & -0.11 & -0.27 & -0.09 \\
NS & 0.030 & 0.019 & 1 & 0.79 & 0.81 & 0.33 & -0.26 & -0.17 & -0.43 \\
FM & $<0.0001$ & 0.031 & 0.034 & 1 & 0.99 & 0.65 & -0.38 & -0.52 & -0.66 \\
FMWC & $<0.0001$ & 0.028 & 0.047 & $<0.0001$ & 1 & 0.60 & -0.38 & -0.50 & -0.64 \\
MC & 0.123 & 0.897 & 0.389 & 0.046 & 0.094 & 1 & -0.25 & -0.70 & -0.69 \\
RF & 0.040 & 0.140 & 0.293 & 0.065 & 0.045 & 0.630 & 1 & 0.10 & 0.36 \\
TSS & 0.037 & 0.090 & 0.709 & 0.032 & 0.036 & 0.013 & 0.243 & 1 & 0.21 \\
TTA & 0.002 & 0.349 & 0.293 & 0.0007 & 0.001 & 0.017 & 0.013 & 0.039 & 1 \\
\hline
\end{tabular}


influence on consumer's preference to smaller fruits. Variation of pineapple fruit acidity and sweetness are associated with the pineapple clone used, fruit maturation and growing conditions [20] [21], but little research has been carried out on the underlying fruit acid metabolism that determines final pineapple fruit acidity [13].

\section{Conclusions}

The results of this study showed the existence of genetic variability in the Turiaçu pineapple population. The estimated parameters indicate that the population of Turiaçu pineapple is suitable for selection of the best clones, especially for Fusarium resistance.

Clones did not differ significantly in relation to total titratable acidity (TTA) and total soluble solids (TSS). However, these traits showed to be negatively correlated to fruit mass. Moreover, these traits in Turiaçu pineapple are better than other commercial cultivars, as showed by Araújo et al. (2012) compared to the data presented here, implying that Turiaçu can be used in breeding programs for improvement of fruit quality.

\section{Acknowledgements}

The authors thank FAPEMA for financial support.

\section{References}

[1] IBGE-Instituto Brasileiro de Geografia e Estatística. (2014) Culturas temporárias e permanentes. [Temporary and Permanent Crops.] Prod. agric. munic, 41, 1-100.

[2] Araujo, J.R.G., Aguiar Júnior, R.A., Chaves, A.M.S., Reis, F.D.O. and Martins, M.R. (2012) Abacaxi "Turiaçu”: cultivar tradicional nativa do Maranhão. [Turiaçu: A Pineapple Cultivar Traditional and Native from Maranhão, Brazil.] Revista Brasileira de Fruticultura, 34, 1270-1276. https://doi.org/10.1590/S0100-29452012000400037

[3] Vencovsky, R. and Ramalho, M.A.P. (2006) Contribuições do melhoramento genético no Brasil. [Contributions of Plant Breeding in Brazil.] In: Paterniani, E., Ed., Ciência, Agricultura e Sociedade, Embrapa, Brasília, DF, 41-74.

[4] Camillo, J., Braga, V.C., Mattos, J.K.A., Lopes, R., Cunha, R.N.V., Padilha, J. And Scherwinski-Pereira, J.E. (2014) Seed Biometric Parameters in Oil Palm Accessions from a Brazilian Germplasm Bank. Pesquisa Agropecuária Brasileira, 49, 604-612. https://doi.org/10.1590/S0100-204X2014000800004

[5] De Resende, M.D.V. (2002) Genética biométrica e estatística no melhoramento de plantas perenes. [Biometric Genetics and Statistic in Perennial Plant Breeding.] Embrapa Florestas, Colombo, PR.

[6] Carvalho, A.D.F.D., Fritsche Neto, R. and Geraldi, I.O. (2008) Estimation and Prediction of Parameters and Breeding Values in Soybean Using REML/BLUP and Least Squares. Crop Breeding and Applied Biotechnology, 8, 219-224. https://doi.org/10.12702/1984-7033.v08n03a06

[7] Santos, A.D., Ceccon, G., Teodoro, P.E., Correa, A.M., Alvarez, R.D.C.F., Silva, J.F.D. and Alves, V.B. (2016) Adaptability and Stability of Erect Cowpea Genotypes 
via REML/BLUP and GGE Biplot. Bragantia, 75, No. 3. https://doi.org/10.1590/1678-4499.280

[8] Torres, F.E., Teodoro, P.E., Sagrilo, E., Ceccon, G. and Correa, A.M. (2015) Interação genótipo $\mathrm{x}$ ambiente em genótipos de feijão-caupi semiprostrado via modelos mistos. [Genotype X Environment Interaction in Semiprostrade Cowpea Genotypes via Mixed Models.] Bragantia, 74, 255-260.

https://doi.org/10.1590/1678-4499.0099

[9] Regis, J.A.V.B., da Silva Molinas, V., Dos Santos, A., Correa, A.M. and Ceccon, G. (2014) Estimativas de parâmetros genéticos em Genótipos de feijão-caupi de porte ereto e semiereto. [Estimates of Genetic Parameters of Cowpea Genotypes Upright and Semi-Erect Plants.] Revista Agrarian, 7, 11-19.

[10] Engel, M.L., Higa, A.R., Andrejow, G.P., Flôres, J., Paulo, C. and Soares, I.D. (2016) Genetic Gain from Different Selection Methods in Eucalyptus macarthurii Progenies in Different Environments. Cerne, 22, 299-308.

https://doi.org/10.1590/01047760201622032197

[11] ISO (1998) 750 Fruit and Vegetable Products: Determination of Titrable Acidity. International Organization for Standarization, Geneva.

[12] Ramsaroop, R.E.S. and Saulo, A.A. (2007) Comparative Consumer and Physicochemical Analysis of del Monte Hawai'i Gold and Smooth Cayenne Pineapple Cultivars. Journal of Food Quality, 30, 135-159. https://doi.org/10.1111/j.1745-4557.2007.00111.x

[13] Chen, N.J., Paull, R.E., Chen, C.C. and Saradhuldhat, P. (2009) Pineapple Production for Quality and Postharvest Handling. Acta Horticulturae, 822, 253-260. https://doi.org/10.17660/ActaHortic.2009.822.31

[14] Chaves, P.P.N., dos Santos, G.R., Alves, A.F., Carline, J.V.G., Lopes, D.A.P.S. and Nascimento, I.R. (2014) Genetic Divergence between Watermelon Lines Selected for Resistance to Pappaya ringspot Virus, Type W. Revista de Ciências Agrárias, 57, 367-372. https://doi.org/10.4322/rca.1419

[15] Stępień, Ł., Koczyk, G. and Waśkiewicz, A. (2013) Diversity of Fusarium Species and Mycotoxins Contaminating Pineapple. Journal of Applied Genetics, 54, 367-380. https://doi.org/10.1007/s13353-013-0146-0

[16] Junghans, D.T., Brasileiro, H.S., Santos, V.J., Cabral, J.R.S. and Matos, A.P. (2005) Herança da resistência à fusariose em abacaxizeiros. [Inheritance of Resistance to Fusariosis in Pineapples.] Fitopatologia Brasileira, 30, 123.

[17] Verardi, C.K., Deon, M., de Resende, V. and Brito, R. (2012) Estimation of Genetic Parameters in Rubber Progenies. Crop Breeding and Applied Biotechnology, 12, 185-190. https://doi.org/10.1590/S1984-70332012000300004

[18] de Lima, V.P. Reinhardt, D.H. and Costa, J.A. (2001) Desbaste de mudas tipo filhote do abacaxi cv. Pérola: 1. Produção e qualidade do fruto. [Slips Thinning from the Pineapple cv. Pérola: 1. Production and Fruit Quality.] Revista Brasileira de Fruticultura, 23, 634-638. https://doi.org/10.1590/S0100-29452001000300038

[19] Caetano, L.C.S., Ventura, J.A., Costa, A. de F.S. da. and Guarçoni, R.C. (2013) Efeito da adubação com nitrogênio, fósforo e potássio no desenvolvimento, na produção e na qualidade de frutos do abacaxi 'Vitória'. Revista Brasileira de Fruticultura, 35, 883-890. https://doi.org/10.1590/S0100-29452013000300027

[20] Bartolome, A.P., Ruperez, P. and Fuster, C. (1995) Pineapple Fruit Morphological Characteristics, Chemical Composition and Sensory Analysis of Red Spanish and Smooth Cayenne Cultivars. Food Chemistry, 53, 75-79. 
https://doi.org/10.1016/0308-8146(95)95790-D

[21] Saradhuldhat, P. and Paull, R.E. (2007) Pineapple Organic Acid Metabolism and Accumulation during Fruit Development. Scientia Horticulturae, 112, 297-303.

https://doi.org/10.1016/j.scienta.2006.12.031 